\title{
Effects of platelet-derived growth factor, vitamin D and parathyroid hormone on osteoblasts derived from cancer patients on chronic bisphosphonate therapy
}

\author{
MYNENI VENKATASATYA SRINIVAS RAO, JASON BERK, SAUD ABDULAZIZ ALMOJALY \\ SAMUEL GOODLOE III, JOSEPH MARGARONE III, MAUREEN SULLIVAN and ROSEMARY DZIAK
}

School of Dental Medicine, The University at Buffalo, State University of New York, Buffalo, NY 14214, USA

Received September 11, 2008; Accepted November 6, 2008

DOI: 10.3892/ijmm_00000145

\begin{abstract}
Bisphosphonates consist of a family of pyrophosphate analogues that are currently being used to treat metastatic bone diseases as well as systemic bone diseases such as osteoporosis. There is accumulating evidence suggesting that patients treated with these bisphosphonates can develop, particularly with invasive dental procedures, osteonecrosis of the jaw. This present study investigated the ability of osteoblastic cells obtained from the alveolar bone of patients on long term intravenous bisphosphonate therapy to respond to agents normally involved in bone regulation and repair. The effects of platelet-derived growth factor-BB (PDGF-BB), 1,25-dihydroxycholecalciferol $\left[1,25(\mathrm{OH})_{2} \mathrm{VitaminD}_{3}\right]$ and parathyroid hormone (PTH) on basic parameters of cell viability, proliferation, and differentiation were studied. Osteoblastic cells from a diagnosed necrotic alveolar bone specimen obtained with consent from a multiple myeloma female patient, and a non-necrotic sample from a breast cancer female patient both on chronic bisphosphonate therapy (zolendronic acid) were successfully cultured. Cells from an alveolar bone specimen obtained from a female donor with no known medical conditions were also studied for comparative responses. The cells were exposed to $1,25(\mathrm{OH})_{2} \mathrm{D}_{3}, \mathrm{PDGF}$, or PTH under various incubation conditions. The osteoblastic cell differentiation marker, alkaline phosphatase activity, was assayed using a biochemical analysis. Cell viability was assessed with an MTT assay which measures mitochondrial activity and cell proliferation with a tritiated thymidine assay. This study on osteoblastic cells grown from a necrotic alveolar bone from a multiple myeloma patient and a non-necrotic sample from a breast cancer patient, both on long term bisphosphonate treatment, suggests that viable cells from the bone are responsive to agents such as PTH, PDGF and $1,25(\mathrm{OH})_{2} \mathrm{D}_{3}$ with changes in
\end{abstract}

Correspondence to: Dr Rosemary Dziak, School of Dental Medicine, The University at Buffalo, State University of New York, Buffalo, NY 14214, USA

E-mail:rdziak@buffalo.edu

Key words: bisphosphonates, osteonecrosis, osteoblasts, plateletderived growth factor, vitamin $\mathrm{D}$, parathyroid hormone alkaline phosphatase activity, proliferation and viability suggestive of normal osteoblastic cell responses observed in cultures from a donor of the same gender and age, but not on bisphosphonate treatment. This work provides a rationale for clinical studies to further assess whether the osteonecrosis that sometimes develops in patients treated with bisphosphonates, can be controlled or prevented by close attention to the levels of bone/calcium regulatory agents and/or, in some cases, therapeutic intervention with PDGF to restore regenerative processes that may be compromised at the necrotic site.

\section{Introduction}

Bisphosphonates, nonmetabolized analogues of pyrophosphate, are increasingly prescribed for the prevention of fractures in osteoporotic bones and for the management of bone turnover in Paget's disease and bone metastasis in a variety of different cancers. As an indication of the widespread use of these drugs, in 2004 alone, 55 million prescriptions for bisphosphonates were written in the US (1). Although these drugs appear to reduce the fracture rate and bone pain associated with metastasis, there is an emergence of reports linking bisphosphonate use to osteonecrosis. There are a number of published case reports and case series with patients on intravenous bisphosphonates experiencing osteonecrosis of the jaw bone $(2,3)$. In addition, there are reports of the osteonecrotic condition in the jaws of people on oral bisphosphonates. Although a recent review concluded that the relevant prevalence of the condition in patients on only oral treatment for osteoporosis is low, it also stated that it is not yet possible to draw further conclusions about the potential association between oral bisphosphonate use and osteonecrosis of the jaw because of possible incomplete reporting and the presence of confounding factors (4). The reports of bisphosphonateassociated osteonecrosis focus on the maxillary and mandibular bones of the jaws, primarily after invasive procedures such as tooth extraction. However, the condition also appears spontaneously although less frequently (3) and there is one report to date describing the condition in the auditory canal (5). Very recently, a case-nested study in a cohort of elderly cardiovascular patients revealed a positive association between oral bisphosphonate use and nonspecific aseptic osteonecrosis (6). 
The etiology of bisphosphonate-induced osteonecrosis is undoubtedly complex, and multifactorial. On a tissue level, because these drugs are not metabolized, high concentrations are maintained within the bone for long periods of time and a decrease in bone turnover occurs. On a cellular level, bisphosphonates bind with great affinity to exposed bone mineral around resorbing osteoclasts. The bisphosphonates are internalized by osteoclasts and disruption of osteoclastmediated bone resorption results (3). Although there are in vitro studies which indicate that these drugs can directly enhance proliferation and differentiation of osteoblastic cells involved in bone formation (7), as noted by Hellstein and Marek (8), the compromise in osteoclastic activity in vivo may result in a shift in the osteoclast/osteoblast axis favoring the development of osteonecrosis secondary to inflammatory responses or invasive surgeries in which regenerative, healing responses must be called into play. Studies have reported that bisphosphonates such as pamidronate and zolendronic acid, given to cancer patients before chemotherapy, can produce significant decreases in angiogenic factors such as vascular endothelial growth factor (VEGF) and platelet-derived growth factor (PDGF) $(9,10)$. Decreases of this nature in the concentrations of factors that have significant effects on osteoblastic and osteoclastic cells can influence the overall effects of the bisphosphonates on bone remodeling and lead to an osteonecrotic condition. Another key element pertinent to both the nature of bisphosphonate-induced osteonecrosis as well as possible therapy for the condition is the manner in which the osteoblastic cells in the bisphosphonate-treated bone are affected in their ability to respond to hormones and growth factors normally involved in the regulation of bone regeneration and remodeling. If the responses of these cells are compromised, either directly because of the high local concentration of the drug, or indirectly due to an altered microenvironment, there can consequently be significant effects on remodeling with a net response leading to necrosis of the tissue.

This present study investigated the ability of osteoblastic cells obtained from the alveolar bone of patients on long term, intravenous bisphosphonate therapy to respond to agents normally involved in bone regulation and repair. The effects of PDGF-BB, 1,25-dihydroxycholecalciferol $\left[1,25(\mathrm{OH})_{2}\right.$ VitaminD $\left._{3}\right]$ and parathyroid hormone $(\mathrm{PTH})$ on basic parameters of cell viability, proliferation, and differentiation were studied since previous studies from many in vivo and in vitro investigations provide a rationale for their potential therapeutic value in the treatment of the underlying basis of bisphosphonate-induced osteonecrosis.

\section{Materials and methods}

Cell isolation, culturing procedures and $1,25(\mathrm{OH})_{2} \mathrm{D}_{3}$ treatment. The donor pool for the osteoblastic cells consisted of patients receiving chronic bisphosphonate therapy. Written informed consent according to the guidelines of the Institutional Human Subjects Committee of the University at Buffalo was obtained in order to use the bone specimens in culture to produce human osteoblastic cells. All bone specimens used in this study were removed as part of normal dental treatment for the patients and would have otherwise been discarded.
Patient A was a female multiple myeloma patient, age 54 years, Caucasian, on long term treatment with zolendronic acid, the most potent bisphosphonate in clinical use. The patient was instructed by the dental surgeon to discontinue the drug for 4 months before oral surgery for extraction of a 3rd molar. Despite this respite from bisphosphonate therapy use, osteonecrosis was observed at the extraction site. The alveolar bone specimen obtained after a debridement procedure conducted by a dental clinician to remove the necrotic bone was cultured under the standard conditions described below. Osteoblastic cells migrated out of the bone specimen after $\sim 8$ weeks and were maintained through 4 passages.

Patient B was a female patient, Caucasian, 68 years old, suffering from breast cancer and on zolendronic acid for 10 years. She was off the treatment for 6 months before oral surgery was performed for a 3 rd molar extraction. The alveolar bone specimen that was obtained was from the immediate extraction site and there was no evidence of previous necrosis. A 7-month follow-up by clinicians revealed no evidence of osteonecrosis at the previous extraction site and healing appeared normal and complete. The culturing of the bone from the immediate post extraction site resulted in cellular outgrowths within 8 weeks, and cultures from these cells were maintained for 4 passages.

Patient $\mathrm{C}$ was a female patient, Caucasian, 50 years old, with no apparent medical condition and no reported use of medications undergoing a routine 3 rd molar extraction. An alveolar bone specimen was obtained from the immediate extraction site where no healing complications were noted.

Culturing of bone specimens. After a thorough cleaning of soft tissue and rinsing in PBS + penicillin-streptomycin, the bone explants from patients $\mathrm{A}, \mathrm{B}$ and $\mathrm{C}$ were cultured in $25-\mathrm{cm}^{2}$ tissue culture flasks in modified $\alpha$ minimum essential medium $(\alpha \mathrm{MEM})+$ L-glutamine $(4 \mathrm{mM})$, supplemented with $10 \%$ fetal calf serum (FCS), penicillin (100 units $/ \mathrm{ml})$, streptomycin $(10 \mu \mathrm{g} / \mathrm{ml})$ and amphotericin B $(0.25 \mu \mathrm{g} / \mathrm{ml})$.

$1,25(\mathrm{OH})_{2} \mathrm{D}_{3}$ treatment. Twenty-four hours before the cells from patients $\mathrm{A}$ and $\mathrm{B}$ were retrieved, confluent cultures were treated with $10 \mathrm{nM}$ of $1,25(\mathrm{OH})_{2} \mathrm{D}_{3}$ diluted in absolute ethanol. Cells treated only with the $1,25(\mathrm{OH})_{2} \mathrm{D}_{3}$ alcohol diluent served as controls. The cells were analyzed for proliferation and alkaline phosphatase (ALP) activity.

MTT cell viability assay. The viability of the cells obtained from patients A and B were determined by the MTT assay $\left(\right.$ Chemicon $^{\circledR}$ International Inc, Temecula, CA). The cells were seeded into $24-$ well plates at a density of $150 \times 10^{3}$ cells $/ \mathrm{ml} /$ well in $\alpha \mathrm{MEM}+10 \%$ FCS medium described above. At day 1 , medium was replaced with fresh $\alpha \mathrm{MEM}+10 \%$ FCS medium in the absence or presence of different concentrations of $1,25(\mathrm{OH})_{2} \mathrm{D}_{3}$. Cells were then incubated at $37^{\circ} \mathrm{C}$ in humidified air containing $5 \% \mathrm{CO}_{2}$ for 3,5 , or 7 days. The MTT cell viability assay was conducted as previously described (11).

Alkaline phosphatase activity. In a similar manner, cell cultures were treated with various concentrations of the test reagents and analyzed for ALP activity as an indicator of osteoblastic cell differentiation (12). After designated periods 


\section{ALP activity 24 hrs}

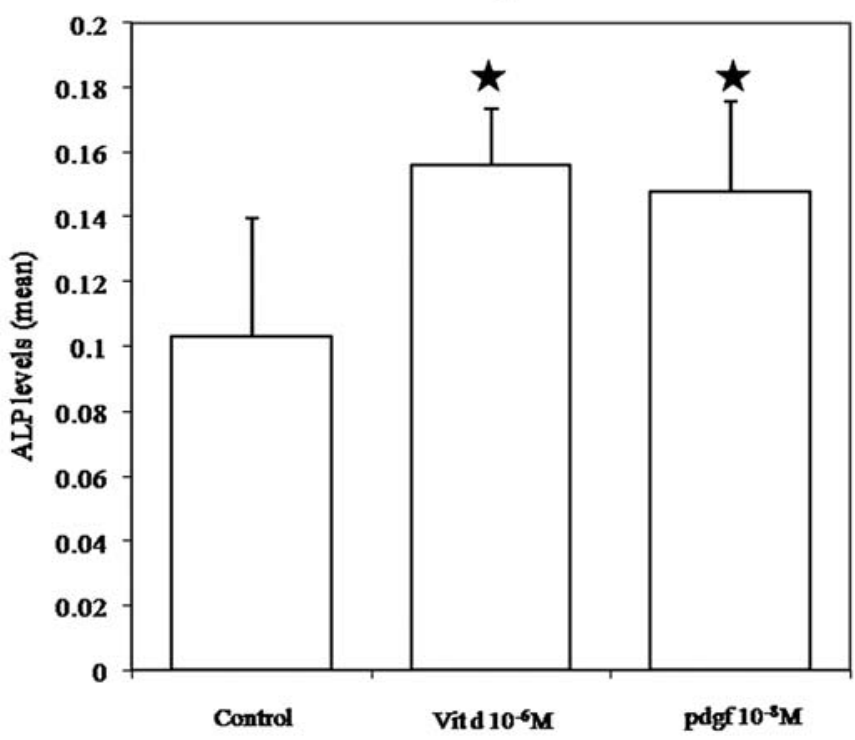

Figure 1. Alkaline phosphatase (ALP) activity of osteoblasts from the necrotic site incubated with $1,25(\mathrm{OH})_{2} \mathrm{D}_{3}\left(10^{-6} \mathrm{M}\right)$ (vitD), PDGF $\left(10^{-8} \mathrm{M}\right)$, for $24 \mathrm{~h}$. The data are the mean \pm SE of ALP levels normalized per amount of protein per sample for 4 samples. The data were statistically analyzed using ANOVA. ${ }^{\star}$ Significantly greater than controls; $\mathrm{P}<0.05$.

of incubation, the cells were lysed with $1 \%$ Triton $\mathrm{X}-100$ at $48^{\circ} \mathrm{C}$ for $1 \mathrm{~h}$. Triplicate aliquots from each lysate were dispensed onto 96-well plates, combined with the substrate para-nitrophenol phosphate in 2-amino-2-methyl-1-propanol buffer (Sigma) and incubated at $37^{\circ} \mathrm{C}$. After 1 h, $0.5 \mathrm{~N} \mathrm{NaOH}$ was added to stop the reaction, and the amount of ALP activity was measured by reading the absorbance at $405 \mathrm{~nm}$ on a microplate reader (Bio-Rad Laboratories). The ALP activities were normalized to the amount of cell protein in each culture by the following procedure. Additional aliquots from each lysate were centrifuged at $13,000 \mathrm{rpm}$ for $1 \mathrm{~min}$ to remove the Triton X-100, and the protein extracts were washed repeatedly and then resuspended in distilled water. Triplicates from each extract were dispensed onto 96-well plates and mixed with the Bio-Rad protein assay reagents. The protein concentration was measured by reading the absorbance at $595 \mathrm{~nm}$ on a microplate reader.

Proliferation studies. Proliferation was studied with $\left[{ }^{3} \mathrm{H}\right]$-thymidine using a methodology previously described for osteoblastic cells from the alveolar bone (13). Once the cell cultures from the donor bones reached $70 \%$ confluency, they were detached by trypsinization and cultured in 24-well plates at a density of 50,000 cells/well. Following a $24 \mathrm{~h}$ incubation, the cells were placed in media containing $0.01 \%$ FCS. During the last $4 \mathrm{~h}$, DNA labeling was accomplished by the addition of $\left[{ }^{3} \mathrm{H}\right]$-thymidine to the wells at a final concentration of $1 \mu \mathrm{Ci} / \mathrm{ml}$. The cells were then washed once with media, followed by a 10-min incubation with ice cold $10 \%$ trichloroacetic acid (TCA), and 3 washes with $10 \%$ TCA. The cells were solubilized with $0.5 \mathrm{~N} \mathrm{KOH}$ $(0.5 \mathrm{ml} /$ well $)$ and incubated for $2 \mathrm{~h}$ at $23^{\circ} \mathrm{C}$. The neutralization reaction was preformed with $1.0 \mathrm{~N} \mathrm{HCl}(0.25 \mathrm{ml} /$ well $)$. Contents of the wells were transferred to scintillation vials and counted in $10 \mathrm{ml}$ scintillation fluid to determine the amount of radioactivity in each sample.

\section{Results}

Fig. 1 shows that $10^{-6} \mathrm{M} 1,25(\mathrm{OH})_{2} \mathrm{D}_{3}$ as well as $10^{-8} \mathrm{M}$ PDGF-BB after $24 \mathrm{~h}$ of incubation at $37^{\circ} \mathrm{C}$ significantly increased the ALP activity levels of the osteoblastic cells isolated from the necrotic site of patient A. Controls in this experiment were cells from the same culture with no agents added. Fig. 2 shows that the cells from the necrotic site of patient A who was on long term zoledronic acid therapy also responded in a fairly typical manner to another bisphosphonate, etidronate, in addition to the vitamin D treatment with an increase in ALP activity. The results presented here reveal

\section{ALP activity 24 hrs}

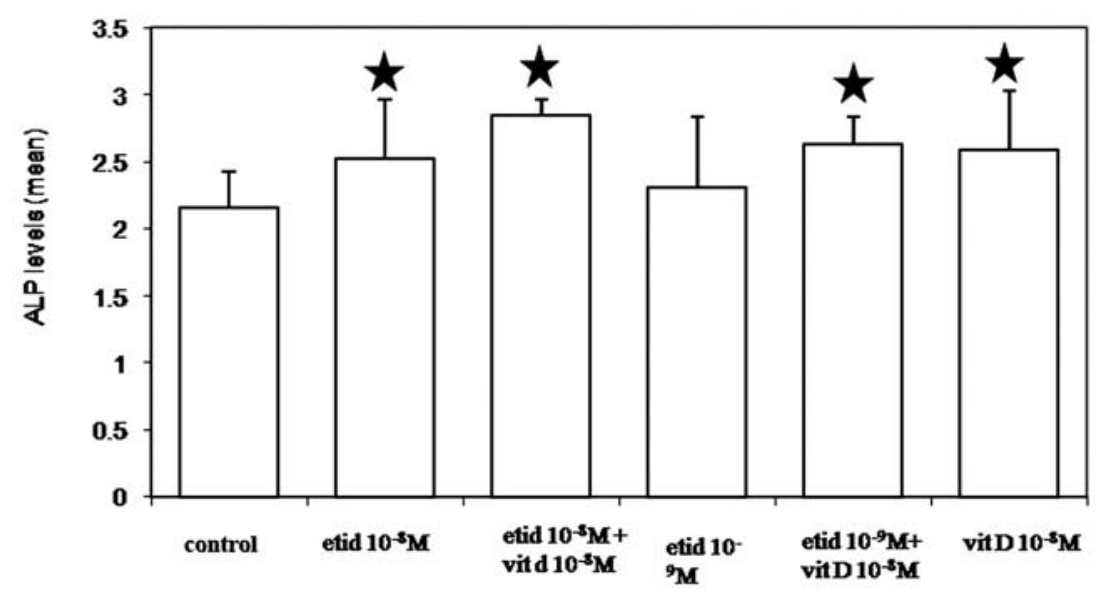

Figure 2. Alkaline phosphatase (ALP) activity of osteoblasts from the necrotic site (patient A) incubated with $1,25(\mathrm{OH}){ }_{2} \mathrm{D}_{3}\left(10^{-6} \mathrm{M}\right)(\mathrm{vitD})$, etidronate (etid) $\left(10^{-8} \mathrm{M}\right)$, for $24 \mathrm{~h}$. The data are the mean \pm SE of ALP levels normalized per amount of protein per sample for 4 samples. The data were statistically analyzed using ANOVA. ${ }^{\star}$ Significantly greater than controls; $\mathrm{P}<0.05$. 
ALP activity 24 hrs

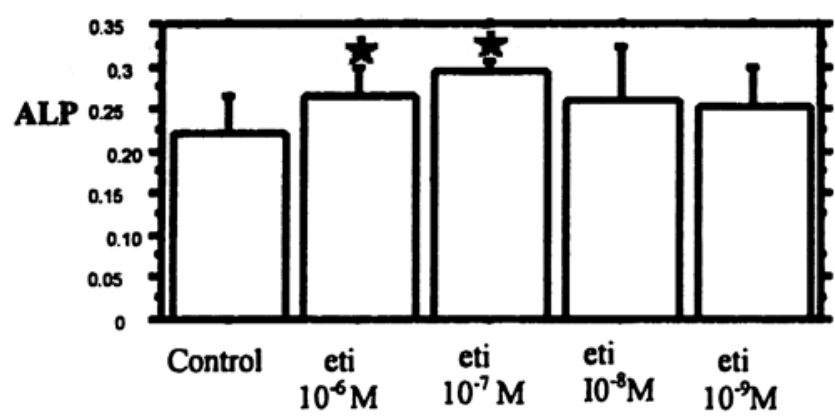

Figure 3. Alkaline phosphatase (ALP) activity of osteoblasts from patient $\mathrm{C}$ (not receiving prior bisphosphonate therapy) incubated with etidronate (eti) or no added agents (controls) for $24 \mathrm{~h}$. Data are the mean \pm SE of ALP levels normalized per amount of protein per sample for 4 samples. Data were statistically analyzed using ANOVA. ${ }^{\star}$ Significantly greater than controls; $\mathrm{P}<0.05$.

that after $24 \mathrm{~h}$ of incubation, etidronate at $10^{-8} \mathrm{M}$ and the mixture of etidronate and vitamin D significantly increased ALP activities in the cells compared to the controls treated without any added agent. The combination of the two agents did not result in significantly greater effects compared with each agent alone. Fig. 3 shows that etidronate evoked a similar effect on ALP activity in osteoblastic cells cultured from an alveolar bone specimen of a donor (patient $\mathrm{C}$ ), without any history of cancer and not on long term zoledronic acid therapy.

Cells from patient $\mathrm{B}$, who was on long term zoledronic acid but did not experience necrosis after an invasive dental procedure, also exhibited responses that are similar to those of normal human osteoblastic cells. The cells from this patient were responsive to in vitro PTH treatment under conditions which typically support this effect in noncancerous, nonbisphosphonate-treated donors. Fig. 4 shows that with short term treatment $(1 \mathrm{~h})$, both $10^{-8}$ and $10^{-10} \mathrm{M}$ PTH increased ALP compared to nontreated controls, whereas long term $(48 \mathrm{~h})$ treatment with these concentrations of PTH had no significant effect and tended to produce decreases compared to the appropriate control values.

Fig. 5 shows that in the cells obtained from patient B proliferation was significantly increased by PDGF at a concentration that typically produces this effect in cells obtained from noncancer patients, not on long term bisphosphonate therapy indicating another similarity in responses to bone regulatory agents in cells from bisphosphonate-treated patients.

Under these same conditions in these cells, PTH did not produce significant effects on proliferation as measured by the tritiated thymidine assay. However, measurements of cellular activity with the MTT assay as shown in Fig. 6, revealed significant increases with short term incubations with PTH concentrations of $10^{-8}$ and $10^{-10} \mathrm{M}$. These data suggest that even though the cells from the non-necrotic site of patient B may not be responsive to PTH with direct increases in cellular proliferation, the hormone may still evoke net positive anabolic effects either with direct increases in cellular mitochondrial activity or via decreases in catabolic events such as apoptosis.

\section{Discussion}

The etiology of bisphosphonate-induced osteonecrosis is undoubtedly complex and multifactorial. One key element pertinent to both the nature of the osteonecrotic condition as well as the possible therapy is the manner in which the osteoblastic cells in the bone are affected in their ability to

ALP ACTIVITY SHORT TERM AMD LONG TERM

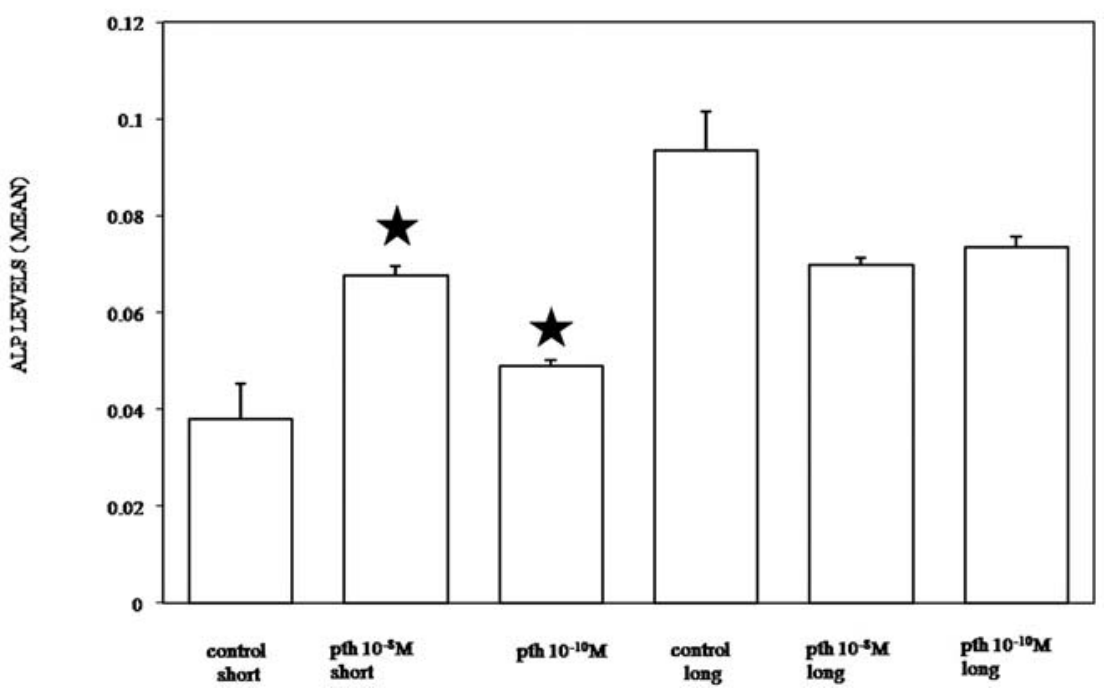

Figure 4. Alkaline phosphatase (ALP) activity of osteoblasts from non-necrotic site (patient B) incubated with PTH for short term and long term periods of time. Short term incubation ( $1 \mathrm{~h}$ ), with PTH at concentrations of $10^{-8}$ and $10^{-10} \mathrm{M}$ significantly increased the ALP activity. The long term incubation of $48 \mathrm{~h}$ with the hormone had opposite effects with decreases compared to the appropriate control. The data are the mean \pm SE of measurements for 4 samples. Data were statistically analyzed using ANOVA. ${ }^{\star}$ Significantly greater than controls; $\mathrm{P}<0.05$. 
Tritiated Thymidineproliferation assay

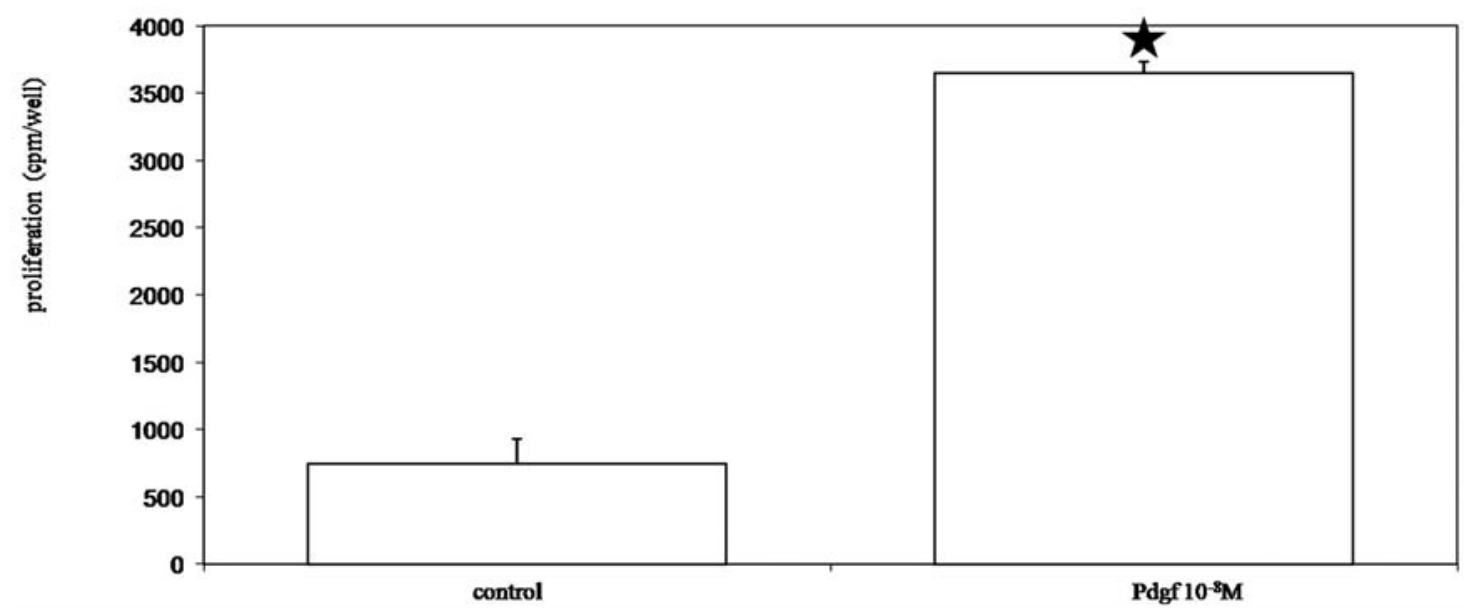

Figure 5. Effects on proliferation of osteoblasts from non-necrotic site (patient B) treated with control (culture media only) or platelet-derived growth factor (PDGF-10-8 M) for $48 \mathrm{~h}$. PDGF $\left(10^{-8} \mathrm{M}\right)$ significantly increased the proliferation compared to the control. Data are the mean \pm SE of measurements for 4 samples. Data were statistically analyzed using ANOVA. ${ }^{\star}$ Significantly greater than controls; $\mathrm{P}<0.05$.

\section{MTT Assay of cell Viability}

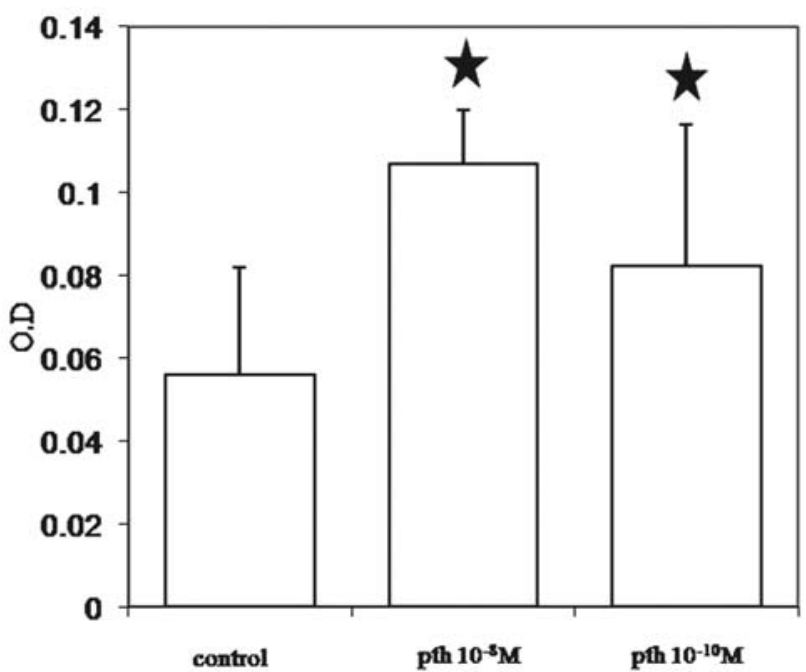

Figure 6. MTT assay with osteoblasts from non-necrotic site (patient B) treated with PTH at concentrations of $10^{-8}$ and $10^{-10} \mathrm{M}$ for short term incubation. At both tested concentrations of PTH, cells show higher viability compared to the control. Data are mean \pm SE of measurement for 3 samples. The data were statistically analyzed using ANOVA. ${ }^{\star}$ Significantly greater than controls; $\mathrm{P}<0.05$.

respond to factors normally involved in bone remodeling. This present study investigated the ability of osteoblastic cells obtained from two patients on long term intravenous bisphosphonates to respond to agents normally involved in bone regulation and repair. The effects of PDGF, $1,25(\mathrm{OH})_{2} \mathrm{D}_{3}$, and PTH on basic parameters of cell viability, proliferation, and differentiation were studied since previous studies from many in vivo and in vitro investigations provide a rationale for the potential therapeutic value of these agents in the treatment or prevention of the condition.

PDGF is present in bone matrix, secreted by platelets during early fracture repair, and produced at fracture sites (14). It is chemotactic and mitogenic for osteoblasts and stimulates the production of the main extracellular component of bone, type I collagen $(15,16)$. In the late 1980 s, Lynch and coworkers were the first to report the positive effects of PDGF on the regeneration of bone, cementum and periodontal ligament (17). Subsequently, there have been extensive studies on the beneficial effects of this growth factor on the wound healing, stimulation of periodontal ligament and alveolar bone cells and regeneration of the periodontium in animal models (18-21). More recently, Nevins et al (22) have demonstrated significant periodontal and osseous regeneration in humans treated with recombinant PDGF-BB (rhPDGF-BB) mixed with demineralized freeze-dried bone allograft (DFDBA), and a product which consists of this growth factor and a calcium phosphate scaffold was approved by the US Food and Drug Administration (US FDA) for use in healing defects of this nature (www.osteo health.com). Since PDGF has been documented to possess a multitude of effects that promote bone and periodontal tissue healing, it appears to be a natural candidate for therapy in oral necrotic conditions, and rhPDGF-BB was given by the US FDA an orphan drug status for use in clinical studies in patients with osteonecrosis of the jaw (www.osteo health.com). Consistent with the possible therapeutic effects of PDGF are the reports of Adornato et al (23) and Curi et al (24) who treated patients with bisphosphonate-induced osteonecrosis with an approach that combined bone resection with autologous platelet-rich plasma, a source of growth factors that include PDGF. This therapy showed favorable results, including complete wound healing in some patients suffering from bisphosphonate induced osteonecrosis. These studies are also consistent with the in vitro results presented here where osteoblastic cells cultured from the alveolar bone 
of a patient on long term bisphosphonates, under optimal incubation conditions, are able to respond to administered PDGF with increases in cell growth and changes in ALP activity similar to responses in osteoblastic cells from normal, nonbisphosphonate-treated donors. In a therapeutic procedure, local clinical application of the PDGF may be able to restore levels of this growth factor that were found in previous studies to have been decreased by bisphosphonate therapy $(9,10)$.

1,25-Dihydroxyvitamin $\mathrm{D}_{3}$ is a metabolite of 25hydroxyvitamin $\mathrm{D}_{3}$ that has a broad range of action in a number of cell systems. While $\mathrm{D}_{3}$ can modulate growth in a number of tumor cells, it is most known for its role in bone cell regulation and calcium homeostasis $(25)$. The role that $1,25(\mathrm{OH})_{2} \mathrm{D}_{3}$ plays in the induction of osteoblastic differen-tiation is well documented, and this agent has many effects on osteoblastic cells related to its overall net effect on bone formation (2528). Of potential importance in understanding the complexity of skeletal responses in patients on long term bisphosphonate therapy during which the levels of angiogenic factors such as VEGF are decreased is the in vitro evidence that the anabolic effects of 1,25-dihydroxyvitamin $\mathrm{D}_{3}$ on osteoblasts are enhanced by VEGF produced by osteoblasts and by growth factors produced by endothelial cells (28).

Likewise, a number of investigators have demonstrated the anti-tumor beneficial effects of $1,25(\mathrm{OH})_{2} \mathrm{D}_{3}$ on a number of different tumors (29-31). Since $1,25(\mathrm{OH})_{2} \mathrm{D}_{3}$ is being considered as a therapeutic agent for tumor patients, it may also prove to have beneficial effects on promoting alveolar bone regeneration in patients with bisphosphonate-associated osteonecrosis of the jaw. The results in the present study which indicate that the osteoblastic cells from the necrotic site are responsive to $1,25(\mathrm{OH})_{2} \mathrm{D}_{3}$ in a predictable manner with evidence of increased ALP activity and cell viability suggest that the cells in a bisphosphonate-treated bone may still be responsive to this factor if other conditions in the microenvironment do not compromise their overall metabolic processes.

A recent study by Badros et al (32) found a high incidence of vitamin D deficiency in multiple myeloma patients with resulting higher serum PTH levels and bone turnover markers. In that study, there does not appear to be an analysis of potential differences in these parameters between the multiple myeloma patients on bisphosphonate therapy compared to those not on the drug, but it is stated that there were no differences in these parameters between patients receiving monthly versus 3-month zoledronic acid therapy. Moreover, in that same study, it was found that in the group of 14 patients (out of the total 100 patients studied) who did develop osteonecrosis of the mandible, there was no significant correlation between osteonecrosis development and the bone turnover markers, $1,25(\mathrm{OH})_{2} \mathrm{D}_{3}$ or PTH levels. However, 7 out of the 14 osteonecrotic patients did have serum $1,25(\mathrm{OH})_{2} \mathrm{D}_{3}$ levels less than $36 \mathrm{nmol} / 1$, which is the level at which vitamin $\mathrm{D}$ deficiency has been defined and another 3 out of the 14 had levels between $36-75 \mathrm{nmol} / \mathrm{l}$ which is defined as vitamin $\mathrm{D}$ insufficiency. In other studies in patients with metastatic breast cancer, there is a suggestion that long term persistence of low serum calcium levels and high serum PTH levels during bisphosphonate treatment can predispose them to osteonecrosis of the jaw (33). Data presented by Ardine et al (33) obtained from a relatively small sample of 13 patients confirmed the results of an earlier randomized registrative study of zoledronic acid in bone metastatic breast patients in which increased PTH was noted in the first months of treatment with a progressive decrease in the later months (34). In the report by Ardine et al (33), however, patients that did develop osteonecrosis had a persistence of relative hypocalcemia and secondary hyperparathyroidism before the development of the osteonecrosis. Further study correlating serum calcium levels as well as vitamin D and PTH levels with the development of osteonecrosis of the jaw needs to be conducted to establish more significant relationships. However, the data in this present study suggest that osteoblastic cells at a necrotic site can be responsive to these bone regulatory agents. There is to date, one case report by Harper and Fung (35) in which intermittent, low dose treatment with PTH was beneficial in the treatment of bisphosphonate-associated osteonecrosis of the mandible instigated at first by endodontic treatment and later aggravated by molar extractions. Although this report did not claim to provide direct evidence to the efficacy of the use of PTH therapy in the treatment of bisphosphonate-associated osteonecrosis of the jaw, in conjunction with our study here on the responsiveness of osteoblastic cells from bisphosphonate-treated patients to the hormone, further research into the potential therapeutic effectiveness for this condition should be pursued.

In summary, the data presented here provide evidence that alveolar osteoblastic cells obtained from cancer patients on long term bisphosphonate treatment can be responsive to bone regulatory agents such as PDGF, $1,25(\mathrm{OH})_{2} \mathrm{D}_{3}$ and PTH with effects on cell viability, proliferation and differentiation as expected for cells obtained from donors not previously treated with bisphosphonates. Although extensive studies with large populations are needed for more definitive results, this study suggests that the osteonecrosis that sometimes develops in patients treated with bisphosphonates can be controlled or prevented by close attention to the levels of bone/calcium regulatory agents and, in some cases, through therapeutic intervention with local application of PDGF to restore regenerative processes that may be compromised at the necrotic site.

\section{References}

1. Silverman SL and Maricic M: Recent developments in bisphosphonate therapy. Semin Arthritis Rheum 37: 1-12, 2007.

2. Woo SB, Hellstein JW and Kalmar JR: Systematic review: bisphosphonates and osteonecrosis of the jaws. Ann Intern Med 144: 753-761, 2006.

3. Ruggiero SL, Mehrotra B, Rosenberg TJ and Engroff SL: Osteonecrosis of the jaws associated with the use of bisphosphonates: a review of 63 cases. J Oral Maxillofac Surg 62: 527-534, 2004.

4. Pazianas M, Miller P, Blumentals WA, Bernal M and Kothawala P: A review of the literature on osteonecrosis of the jaw in patients with osteoporosis treated with oral bisphosphonates: prevalence, risk factors, and clinical characteristics. Clin Ther 29: 1548-1558, 2007.

5. Polizzotto MN, Cousins V and Schwarer AP: Bisphosphonateassociated osteonecrosis of the auditory canal. Br J Haematol 132: 114, 2006.

6. Etminan M, Aminzadeh K, Matthew IR and Brophy JM: Use of oral bisphosphonates and the risk of aseptic osteonecrosis: a nested case-control study. J Rheumatol 35: 691-695, 2008. 
7. Reinholz GG, Getz B, Pederson L, et al: Bisphosphonates directly regulate cell proliferation, differentiation, and gene expression in human osteoblasts. Cancer Res 60: 6001-6007, 2000.

8. Hellstein JW and Marek CL: Bisphosphonate osteochemonecrosis (bis-phossy jaw): is this phossy jaw of the 21st century? J Oral Maxillofac Surg 63: 682-689, 2005.

9. Santini D, Vincenzi B, Avvisati G, Dicuonzo G, et al: Pamidronate induces modifications of circulating angiogenic factors in cancer patients. Clin Cancer Res 8: 1080-1084, 2002.

10. Santini D, Vincenzi B, Dicuonzo G, Avvisati G, et al: Zoledronic acid induces significant and long-lasting modifications of circulating angiogenic factors in cancer patients. Clin Cancer Res 9: 2893-2897, 2003.

11. Plumb JA: Cell sensitivity assays: the MTT assay. Methods Mol Med 88: 165-169, 2004

12. Perinpanayagam H, Martin T, Mithal V, Dahman M, Marzec N, Lampasso J and Dziak R: Alveolar bone osteoblast differentiation and Runx2/Cbfa1 expression. Arch Oral Biol 51: 406415, 2006.

13. Lampasso JD, Marzec N, Margarone J III and Dziak R: Role of protein kinase $\mathrm{C}$ alpha in primary osteoblastic cell proliferation. J Bone Miner Res 17: 1968-1976, 2002.

14. Canalis E, McCarthy TL and Centrella M: Growth factors and the regulation of the bone remodeling. J Clin Invest 81: 277-281, 1988.

15. Centrella M, McCarthy TL and Canalis E: Platelet-derived growth factor enhances deoxyribonucleic acid and collagen synthesis in osteoblast-enriched cultures from fetal rat parietal bone. Endocrinology 125: 13-19, 1989.

16. Centrella M, McCarthy TL, Kusmik WF and Canalis E: Isoform-specific regulation of platelet-derived growth factor activity and binding in osteoblast-enriched cultures from fetal rat bone. J Clin Invest 89: 1076-1084, 1992.

17. Lynch SE, Williams RC, Polson AM, Howell TH, Reddy MS Zappa UE and Antoniades HN: A combination of plateletderived and insulin-like growth factors enhances periodontal regeneration. J Clin Periodontol 16: 545-548, 1989.

18. Park JB, Matsuura M, Han KY, Norderyd O, Lin WL, Genco RJ and Cho MI: Periodontal regeneration in class III furcation defects of beagle dogs using guided tissue regenerative therapy with platelet-derived growth factor. J Periodontol 66: 462-477, 1995

19. Cho MI, Liu WL and Genco RJ: Platelet-derived growth factormediated guided tissue regenerative therapy. J Periodontol 66: 522-530, 1995

20. Giannobile WV, Hernandez RA, Finkelman RD, Ryan S, Kiritsy CP, D'Andrea M and Lynch SE: Comparative effects of platelet-derived growth factor-BB and insulin-like growth factor-I, individually and in combination, on periodontal regeneration in Macaca fasciculars. J Periodont Res 31: 301-312, 1996.

21. Anusaksathien O, Jin Q, Zhao M, Somerman MJ and Giannobile WV: Effect of sustained gene delivery of plateletderived growth factor or its antagonist (PDGF-1308) on tissueengineered cementum. J Periodontol 75: 429-440, 2004.
22. Nevins M, Camelo M, Nevins ML, Schenk RK and Lynch SE: Periodontal regeneration in humans using recombinant human platelet-derived growth factor-BB (rhPDGF-BB) and allogenic bone. J Periodontol 74: 1282-1292, 2003.

23. Adornato MC, Motcos I and Rozanski J: The treatment of bisphosphonate-associated osteonecrosis of the jaws with bone resection and autologous platelet-derived growth factors. JADA 138: 971-977, 2007.

24. Curi MM, Cossolin GSI, Koga DH, Araujo SR, Feber O, dos Santos MO and Zardetto C: Treatment of avascular osteonecrosis of the mandible in cancer patients with a history of bisphosphonate therapy by combining bone resection and autologous platelet-rich plasms: Report of 3 cases. J Oral Maxillofac Surg 65: 349-355, 2007.

25. Holick MF: The role of vitamin D for bone health and fracture prevention. Curr Osteoporos Rep 4: 96-102, 2006.

26. Manolagas SC, Burton DW and Deftos LJ: 1,25-Dihydroxyvitamin D3 stimulates the alkaline phosphatase activity of osteoblast-like cells. J Biol Chem 256: 7115-7117, 1981.

27. Chavassieux P, Boivin G, Terrier C, Serre CM, Lagarde D and Meunier PJ: Effects of 1,25 dihydroxyvitamin D3 on the morphology and alkaline phosphatase activity of ROS 17/2,8 osteoblastic cells: influence of time and dose. Reprod Nutr Dev 30: 439-443, 1990.

28. Wang DA, Miura M, Demura H and Sato K: Anabolic effects of 1,25-Dihydroxyvitamin D3 on osteoblasts are enhanced by vascular endothelial growth factor produced by osteoblasts and by growth factors produced by endothelial cells. Endocrinology 138: 2953-2962, 1997.

29. Sou H, Koike M, Elstner E, Cambell M, Le J, Uskokovic MR, Kamada N and Koeffler HP: 19-nor vitamin-D analogs: a new class of potent inhibitors of proliferation and inducers of differentiation of human myeloid leukemia cell lines. Blood 92: 2441-2449, 1998

30. Zhang X, Nicosia SV and Bai W: Vitamin D receptor is a novel drug target for ovarian cancer treatment. Curr Cancer Drug Targets 6: 229-244, 2006.

31. Spina CS, Tangpricha V, Uskokovic M, Adorinic L, Maehr H and Holick MF: Vitamin D and cancer. Anticancer Res 26: 2515-2524, 2006

32. Badros A, Goloubrva O, Terpos E, et al: Prevalence and significance of vitamin D deficiency in multiple myeloma patients. Br J Haematol 1: 1-3, 2008.

33. Ardine M, Generali D, Donadio M, et al: Could the long-term persistence of low serum calcium levels and high serum parathyroid hormone levels during bisphosphonate treatment predispose metastatic breast cancer patients to undergo osteonecrosis of the jaw? Ann Oncol 17: 1336-1337, 2006.

34. Elder G: Pathophysiology and recent advances in the management of renal osteodystrophy. J Bone Miner Res 17: 2094-2105, 2002

35. Harper RP and Fung E: Resolution of bisphosphonateassociated osteonecrosis of the mandible: possible application for intermittent low-dose parathyroid hormone [rhPTH(1-34)]. J Oral Maxillofac Surg 65: 573-580, 2007. 